\title{
WHEN YOURS AND MINE ARE (NOT) OURS: RECLAIMING PERSONAL AND NATIONAL HISTORIES IN TIM BUTCHER'S THE TRIGGER: HUNTING THE ASSASSIN WHO BROUGHT THE WORLD TO WAR
}

Željka Babić, University of Banja Luka, Bosnia and Herzegovina, zeljka.babic@ flf.unibl.org

10.31902/fll.26.2019.4

UDK 82.09-31:930.85

\begin{abstract}
Even though the WWI ended a century ago, it seems viable to say that its presence and consequences are still echoing in the (sub)conscious self of the peoples in the Western Balkans. This paper focuses on disclosure of possible linguistic traits within a literary text, which uncover the author's attitude towards the cultural and historical events he depicts. The aim is to investigate the possibility of extracting the parallel personal and general histories, their overlapping points, be they cultural or historical, through the linguistic tools used. The main focal point is on juxtaposing information, whose meaning is overtly shaped by the culture(s) of the speaker and the generally accepted cultural and historical posits, within the stories portrayed.
\end{abstract}

Keywords: culture, history, travel writing, linguistic traits, intramental translation.

\section{Introduction}

The centennial anniversary of the Great War called for novel approaches to the core issues of its aftermath and contemporariness. Therefore, it seems odd that the emergence of Tim Butcher's book The Trigger: Hunting the Assassin Who Brought the World to War, has not been received with much notice in the region of the Western Balkans, even though the academic community (e. g. Markovich 2015) has paid it some attention. Tim Butcher, a British journalist and a wartime news reporter from Bosnia, gives himself a challenging task of portraying Gavrilo Princip, an underage student from western Bosnia, who is, deictically, pinpointed as the trigger of the Great War. Encompassed as a personal account and contribution to unveiling the enigma hovering over the contradicting attitudes towards the very event that ignited the bloodiest conflict in the known history of the time, the author uncovers his own history, which somehow roots on the events presented in his story.

At the same time, the establishment of a reshaped map of the Western Balkans landscape indubitably opens possibilities to take a break and summarise 
holistically the particular literary contributions, whose aim was the uncovering of the topics which were deemed notorious or non-profitable for covering and which presented themselves as the obvious choice with the raised novel interest of both the public and, more importantly, the market. The chosen key term used here, the market, offers itself naturally. Namely, it seems only natural that such an occasion would call for manifold approaches to the topic, academic or non-academic ones, and that the influx of versatile array of publications can only be steered by the publishing houses' editorial policies.

\section{The Contemporary Melange: Travel Writing as a Connecting Link Between Lingua-cultural and Literary Research}

The amalgam, which the Western Balkans area presents, asks for a specific and cautious approach towards choice of research points. It would not be mere generalising to say that the moment one finds a focal investigating point, more problems offer themselves at the first glance in comparison with the benefits. And in the case of Bosnia and Herzegovina, such a standpoint can be taken as an understatement, for everything is looked through a three-glass prism of loosely nationally based 'truths'. So, the very point of writing travelogues has somehow been left aside, for the existence of one versus three or more truths keeps on lingering not only above the authors' heads but also above the recipients' ones. It seems as if the peoples are used to relying on the Other as the source for comparison of their everyday lives. The general public of Bosnia and Herzegovina most often turn to two sources, Evliya Çelebi's The Book of Travels and Rebecca West's Black Lamb and Grey Falcon. More recently, the travel histories about the country have started to emerge, those being recounts of their authors on their (usually war or post-war) imagery of the country. Again, the recounts have been made by aliens and represent the imagery of a Bosnian and Herzegovian peoples, lives and cultures through the eyes of the Other. The geo-political heritage of tell-tale and belief in ever-so-often rewritten myths are just two reasons for the allure Bosnians and Herzegovians feel towards seeing themselves through the eyes of the outer Others, for the nearness of the image through the eyes of the neighbour is an everyday thing, imposed on them by the very environ they have been living in.

The research on travel has been reflourishing in the recent couple of decades. As Thompson $(2016, \mathrm{xvi})$ states, it is

a burgeoning field of academic enquiry. With many societies around the world confronting complex issues of globalization, cultural hybridization and the large-scale flow of populations both within and across national borders, scholars have been increasingly impelled to historicize and theorize these and related phenomena. 
In this particular recipe of the travel writing studies, it is impossible to separate the particular ingredients from the whole. Yet, linguistically challenging seems the number of -isations and -ises used, as well as the usage of the passive voice. It seems as if the researchers have been driven into researching the points by an outer force, or, at least, the very source of imposition is not as important as the very act. Clinging behind the curtain represented through words and phrases such as globalisation or cultural hybridisation, the travel writing studies voice an ever so fresh and vibrant need for broadening the mind through exposure to other cultures, languages, peoples and ways of life and thinking.

When talking about the genre of travel writing in general, Robyn Davidson $(2002,6)$ reminds us that the allure it gives us lies in the fact that "[T]hey create the illusion that there is still an uncontaminated Elsewhere to discover." Thompson $(2011,5)$ praises its usefulness in academic discussions, but warns against impetuous and biased readings, which are done "so as to decipher and critique their larger ideological implications and geopolitical consequences." Pratt $(1992,4)$ emphasises the existence of so-called "contact zones," which for her represent "social spaces where disparate cultures meet, clash, and grapple with each other, often in highly asymmetrical relations of domination and subordination." Bracewell and Drace-Francis (2008) place the area of Bosnia and Herzegovina into the geographical area of Eastern Europe, emphasising its connection with both the Ottoman and Austro-Hungarian Empires. Krivokapić and Panajoti (2018) make the connection with the past by claiming the presence of postcolonial influence in the travel writing texts in the area of the Balkans. Lisle (2006) presents a critical overview of the influence of travelogues onto world politics, with a special attention being paid to Bosnia. She notices that they are "engaged in delivering time/space-specific facts and events to audiences in intelligible ways" and emphasises the connection it makes between the real and the fictional, saying that "it is well positioned to contest the hierarchy of literature that prevents us from identifying important discursive connections between different types of writings" (Lisle, 33). On the other hand, Goldsworthy (2012) talks about the literary colonisation of the Balkans, which is done with the aid of travel writers, whose role is the assessment of the territory as a possible field for the design of stories which can be embraced by the ever-sodemanding market.

Having said that, it is evident that the majority of linguistic issues have been dealt with as a part of general literary or cultural investigations, thus proving that it is almost impossible to draw a strict border between the complementary dichotomy (or trichotomy). Smethurst $(2015,100)$ gives a rather specific view on the topic: 
The history of place-writing in fiction and travel writing is a history of mimesis, leading to (over-)familiarization, containment and the systematization of place. For place-writing to reclaim its agency and difference, the subaltern role of place must be reversed, by recognizing, for example, how our relations with place shape us and how place inhabits us. As an imaginative exercise, we might even begin by considering how place regards us. The tactics of the geocritical imagination might then be summarized as attempts to find for place: a voice, a language, a geo-centric logic, a form, a body, a self-organizing process and something like, but also unlike, a consciousness. The idea is not to abandon the historic study of place as an anthropocentric project, as this remains an indictment of who we were and continue to be.

The significance the intertwined embroidery of the town and its language has with the narrative of the author's representation is in an even larger connection with the historical background and its intricacies, which are sometimes taken for granted or just not possible for transfer. Therefore, for a linguist, it is vital to observe and extrapolate the instances of linguistic evidence, which unequivocally prove the presence of the author's self within the presented narrative and to investigate the possible linguistic tools used to stir readers in the direction the author sets.

The impossibility of separation between literary and cultural research is evident in the same way as is the one between linguistic and cultural. The impossibility of the extraction lies in the core of the research subject, for the term language includes culture in itself. It is, therefore, no surprise that Tannen $(1986,30)$ reminds us that "the fate of the earth depends on cross-cultural communication," again putting the equation sign between linguistic and cultural posits, or, at least, underlines their overlapping scopes and nature. The points of view are sometimes juxtaposed, but they, nevertheless, acknowledge the link. Crozet and Liddicoat $(2002,22)$ appreciate the complexity the concept carries emphasising its "dynamism inherent" and "subject[ness] to change," Risager $(2003 ; 2006)$ talks about "neutralising" the existence of the dichotomy between language and culture by reintroducing "languaculture," and she claims that "linguistic practice is accompanied by languaculture" (Risager 2007, 154). It is evident that applied linguists warmly embrace the concept propagated by anthropological linguists (Agar 1991; 1994) and discourse analysts (Fairclough 1992) in order to narrow the unnatural gap that sometimes seems to exist between the two concepts. Still, recently, some loud voices have been heard calling for reconsiderations and reevaluations of not only the concept of culture but also its implications for the researchers, especially because it has been noted that many scholars follow the tendency of avoiding even the use of the 
term, or, as Atkinson $(2015,424)$ argues, "[I]n the very field which innovated the concept in fact - anthropology - culture has been 'half-abandoned'." The way out from this rather inconvenient pathway has been offered in the form of cultural linguistics (Langacker 1994; Palmer 1996; Farzad 2017). The very return to understanding of the relationship which exists between language, culture and thought for a linguistic researcher opens a possibility for applying posits to a literary text and investigating the possible occurrence or presence of specific linguistic traits.

Lastly, Wierzbicka $(2003,9)$ emphasises her own views on the actual studies of culture by extrapolating that

if we want to study cultures other than our own all we can do is to describe them through the prism of our own culture, and therefore to distort them. We can find a point of view which is universal and cultureindependent; but we must look for such a point of view not outside all human cultures, (because we cannot place ourselves outside them), but within our own culture, or within any other culture that we are intimately familiar with.

It is, therefore, important to include a self-image and self-perception in cultural study. When one transposes such a point at travel writing texts, which are a compendium of self-images and self-perceptions, it seems only natural to try to separate the personal from the generally recommended/reevaluated posits of the narrator, which consequently serve as a leading thread in deciphering the offered narrative and its underlying tale and story.

The theoretical framework indubiously offers different angles for approaching the task set, that of the possibility of unveiling linguistic traits within a literary text. The choice of one piece of literary work, in this case a travelogue, just seemed right for investigating whether it is possible to use basically linguistic tools in order to extract some deeper linguistic levels. Sinclair $(2004,51)$ tells us that

literature is a prime example of language in use; no systematic apparatus can claim to describe language if it does not embrace the literature also; and not as a freakish development, but as a natural specialization of categories which are required in other parts of the descriptive system. Further, the literature must be describable in terms which accord with the priorities of literary critics.

Still, while the focus of literary criticism may be pointed in the other direction, the use of one encircled literary text as a corpus for lingua-cultural con- 
siderations can be justified as a cross-sectional qualitative case study (Dörnyei 2007; Podesva and Sharma 2013), for the scope of the text and its uniqueness and definiteness create an excellent ground for elicitation and extraction of (un) biased cultural issues, which are used, consciously or unconsciously, to guide the readers in the direction intended by the narrator.

\section{Unveiling Linguistic Traits}

Focusing on lingua-cultural, to be more precise personal idolectal traits of the author and the characters of Tim Butcher's The Trigger: Hunting the Assassin Who Brought the World to War, I will try to elude the possible subjective interpretation of a literary text, which is rather expected, for my aim is to focus on merely linguistic structures and units which, either covert or overt, enable uncovering the author's attitude towards the chosen focus of his investigations. The choice of the text as a corpus has been twofold. The personal one deals with the interest in the contemporary views of Gavrilo Princip as well as the actual connection of the character and the author with my home town, Tuzla. And this is the point at which the personal bond both starts and stops. Still, it is worth mentioning, for the examined corpus is a garland of personal innuendoes and fortuities for both the researcher and the author. The other is primarily research-oriented, for the applicability of a linguistic investigation of a travel writing text rarely offers itself in such a way as this has, for it offers a multilateral view of the text, without it being valued through the literary prism.

The complexity of the narrative used in the corpus asked for a narrower, specific approach to a research focal point: the extraction of specific linguistic features within the text which reveal the author's attitude towards the culturalhistorical events he is investigating. The examples investigated are predominately from the opening part of the novel, for it provides an array of both personal and general ideas set in front of readers to be chosen at their own convenience or preference. The further the narrative leads us into the unfolding of the story, the more personal the narrator becomes, thus opening the possibility of subjective reading on both the part of the reader and the part of the analyst. I claim that it is possible to extract the parallel personal and general histories in the investigated corpus, which, on the surface, seem linguistically unmarked and semantically unbiased. Namely, according to ethnolinguistic postulates, "language is highly sensitive to cultural and societal processes" (Gladkova 2015, 47), so it is highly unlikely that the narrative is able to discard completely the personal (therefore, marked or biased) agenda, even when we talk about a piece of a text which, on the surface, comes across as a travelogue.

The author uses the first person singular as a way of leading us through the story, thus limiting it to his own personal ordeal. Such a posit not only opens 
him to the possible critical considerations but also cunningly excuses him from the subjectivism, which, whether we like it or not, must exist with all of us.

Let us consider the depiction which introduces the actual choice of the topic of the book, that of the chapel where Gavrilo Princip was interred.

It was about the size of an electricity substation, a modest structure with a box design, easy to overlook. It wore the livery of so many wartime buildings in Sarajevo: a cavity from what appeared to be an artillery strike, terracotta roof tiles rucked out of alignment, the door ripped from its hinges, its frame pockmarked by shrapnel. (Butcher 2014, 5)

The description resembles an expected depiction of an edifice from wartorn Bosnia. We encounter an extraposed sentence, with a line of coordinated extraposed subjects, used as an introductory canvass. The second sentence follows the rhythm introduced in the first one, that of the simple subject, predicate and the complex complement. The rhythm here changes dramatically as we are faced with the line of coordinated nominal structures, in which the postmodification widens progressively and linearly towards the end, which indubitably emphasises the underlined aura of war. The culmination of the depiction is seen in the appearance of the plaque, which bears the name of Gavrilo Princip written in Cyrillic alphabet. The author's setting is elaborate. It is also in line with the previous trail of a personal confession, which uncovers the reasons for covering the paths of Princip and trying to untangle the Bosnian knot which seems too complicated for him. The knot being "the filthy tomb" (Butcher 24), "the fouled tomb" (Ibid, 21), viz. the use of the chapel as a lavatory during the war. Here is a good time to stop and reconsider Judith Butler's $(1997,38)$ consideration of the relationship between language and trauma, for she posits that

there is no purifying language of its traumatic residue, and no way to work through trauma except through the arduous effort it takes to direct course of its repetition. [...] After all, to be named by another is traumatic: it is an act that precedes my will, an act that brings me into a linguistic world in which I might then begin to exercise agency at all.

The clash between the premodifying adjectives and nouns they modify introduces the clash, which will overtly be present throughout the novel, the clash between the personal narrative retold and the possible existence of yet another truth (however implausible it may be due to the ample amount of presented evidence). Again, this is my personal reading of the author's story, and it is as subjective as a personal reading may be, there is no doubt about that. It carries in itself as much of my personal trauma and remembrance as the au- 
thor's does of his. But the very possibility and openness to such a reading and understanding is of crucial importance, for it allows a personal involvement in the narrative and its encapsulation into a unique personalised experience. Thus, the linguistically expressed dismay needs some kind of elaboration and explanation. And the author's solution is a very interesting one, to "follow Princip's life path, trekking where he trekked" (Butcher 24).

This constant reminder of the existence of a personal agenda keeps on hovering above the readers' heads and they are repeatedly reminded of it. In some moments, it seems that the inevitable first person pronoun prompts us that we, as readers, also must involve ourselves in the story, and, in such a way, become entangled and involved in the story and the journey. This carefully planned representation has been presented on a thin line between personal and general, thus being left for interpretations and multi-faceted readings.

Let us consider also the introduction of the personal history of the author himself. He meticulously gives details about his date and place of birth, depicts not the family history but also the geographical background of the area he comes from. He insists on telling us all the personal details which provoked his involvement in the research he conducted (death of Uncle Alyn, childhood games, his choice of university and department, etc.). This insistence on the personal, therefore subjective enables the depiction of the later events in the same way. By showing that we, after all, are influenced by the societal, linguistic or cultural environs and by genealogical and heritable histories, which are inserted into our minds, voluntarily and involuntarily, the author reminds us that subjectiveness is a part of one's self and that writing a tale must include reclaiming the already written ones and rewriting them using our own personal recognisable style and handwriting. For example, the separating line between the personal and the general can be seen in the choice of sentences.

On 24 March 1918, days after this picture was taken, Uncle Alyn was lost while strafing German trenches. He was twenty-three. He has no known grave.

His parents had to endure months of uncertainty about whether he might have survived. He came down close to the Somme River during an intense German offensive and at a time when the British army was in pell-mell retreat. With thousand of casualties on both sides, the fate of a single enemy aircraft on land recently and bloodily fought over was hardly a priority for the advancing Germans. It would be months before British officialdom formally pronounced that Alyn was dead. (Butcher 14) 
The sentence rhythm changes in accordance with the issues presented. Namely, the facts are presented using straightforward short sentences, which are short of excessive modification. But the instances, which show inclusion of emotions of the other are heavily modified with adjectives, without giving precedence to any of the sides presented. Still, the usage of extraposition in the last sentence makes the reader wonder whether the focalisation is used for syntactic reasons only or the author is trying to highlight his rather bias standpoint against the doer of the action and reprehend the authorities for dawdling.

We also encounter the depictions of preconceived truths and positions, which are rooted (or implanted) into the Western worldview.

the Balkans, a region synonymous in Western eyes with impenetrability, backwardness and violence. (Butcher 6)

this land of mountain and myth. (Butcher 4)

As a native Bosnian, who spent her student years in Sarajevo, I cherish this imported view of the homeland. At the same time, it is so alien, so other, for I have always felt that my homeland is full of meadows and rivers and lakes, and that the greyness of the mountains presents only the backdrop for the actual greenery of the landscape and blueness of the waters. So here, at the very beginning of the story, the paths of the other and of me as a reader both cross and separate, for the established idea about the roughness of the people and their "backwardness," presented just a couple of pages apart, will inevitably provoke a feeling of uneasiness with a reader from this part of the world. The generalness of the idea, the very notion of Balkanness, is something that the people from the Balkans have strong emotions towards, so the acknowledgement that there still exists such a notion, even though in this case the readers are guided into consideration of the last decade of the previous millennium, must inevitably involve the emergence of emotions. Moreover, as it is usually the case, the presumed Western includes the Greek, and the Greeks are the inseparable ingredients of the Balkan concoction. The very image drawn by the metaphor, which describes the beauty of the country is being crushed to pieces by the use of the three coordinated noun phrases, thus putting a sign of negation between the country and its inhabitants.

In line with the previous examples are the lines about the romanticised tales and histories.

wantonly destroying [...] - anything contributed, no matter how marginally, to Bosnia's nascent sense of national identity. (Butcher 6) 
Lying where Europe's south-eastern fringe comes up against influences from Asia Minor, Bosnia had a back-story dominated for hundreds of years by foreign occupation, first by the Ottoman Empire then by Austria-Hungary (otherwise known as the Habsburg Empire). Although its people shared the same language and cultural roots, cleavages over the centuries had created three identifiable groups: Bosnian Serbs, Bosnian Croats and Bosnian Muslims. I read repeatedly how the era foreign domination had been ended by the First World War when a new nation, Yugoslavia, emerged out of the fighting, one that allowed local Slavs to rule themselves for the first time in the modern era. (Butcher 7)

The narrative seems to offer yet another telltale story of the limited flashback into Bosnian and Herzegovian history, i.e. only up to the Ottoman times, which is in sharp contrast with the phrase "nascent sense of national identity," which definitely has deeper roots. The second sentence emphasises an attempt to make a linguistic (and every other) distinction between the ethnic groups, which, again, looks like pure deictic (however plausible) pointing at the core of a still painful and unacknowledged matter-of-fact present-day situation. The readers are again appointed with a conclusion which presents them with little choice, for the conclusiveness of the existence of the three "identifiable" groups inevitably leads to their possible conflict, either in the past or future. The danger of setting borders between ethnic and any other groups has proven to be perilous in Bosnia and Herzegovina in the 1990s, for this type of labelling make possible the division not only between the ethnic groups themselves but with the language(s) they speak and culture(s) they belong to. Moreover, the reference to a romanticised tale of the birth of a nation seems very naive from the local point of view, but in line with the alien presupposed image of both Yugoslavias and their citizens.

Now and then, in order to change the rhythm and give more credibility to the story, the narrator loudly voices his presence with the combination of the first persona singular pronoun and a critical comment on the event discussed.

But the crisis still needed a spark to detonate the explosive mix of old-world superiority, diplomatic miscalculation, strategic paranoia and hubristic military overconfidence. And, like generations of young students before and since, I had been taught that the First World War began after the heir to the Austro-Hungarian Empire, Archduke Franz Ferdinand, was shot in Sarajevo by Gavrilo Princip. Academics still debate the diplomatic-political multiplier that transformed a Balkan assassination into a casus belli for the Great 
Powers, but none dispute that it was the shooting in Sarajevo that led the world to war a century ago. (Butcher 19)

The coordinated noun phrases in the first sentence are in huge contrast with the passive voice in the second. The position of the agent subject, in the case of passivisation, a prepositional complement put at the topically marked final position shows that the narrator wants his readers to be aware that there does not exist a hundred percent agreement with the presumed history embraced and acknowledged by the majority, for the absence of deixis and the very use of the passive voice tell us that the main focus is on the perpetrator not the action itself (even though the use of passive tells us differently on the first glance). The last sentence shows clearly that the language used discloses the inner understanding and point of view of the narrator. Namely, the relative generalness of the statement, underlined with the use of the present simple tense, is sharply contrasted with the use of extraposition, which can be understood not only as a generally agreed issue but also as a starting and finishing point that will ultimately be reached by the quest taken by this particular narrator.

Let us end the discussion with the question the author asks himself at the beginning of this quest for the new truth(s):

But the Princip's fouled tomb led me to think again. It dislodged in my mind a troubling piece of Great War flotsam: the thought that, in the eyes of some of his own people, Princip and his cause were not worth honouring. The filth I found in that memorial chapel polluted the purity of the sacrifice made by Uncle Alyn, the four men from Hellidon, the legions lost on the Western Front, the Italians buried in the snow and millions of others. (Butcher 20)

Hanenberg $(2018,2)$ argues once again in favour of the introduction and implementation of the term intramental translation, by which he means "the process of coming to terms with experience by establishing its meaning." He emphasises the work of anthropologists who draw attention to a so-called "shared intention" to human culture and development, which is understood as "the ability to understand the other's intention and to join one's own intention to it, to transform the other's intention into one's own." Hanenberg, thus, argues that "sharing intention is intramental translating" (Ibid). The misunderstanding which stands in front of Butcher, that of not understanding the reasons of Princip's compatriots for not honouring him just adds value to the notion that the ability of an individual to decipher, understand, embrace actually presents his/his ability to translate, to comprehend, to value. In order to be able to understand the standpoints of Princip's compatriots, Butcher has to be 
able to translate the cultural background imprinted in their minds. Thus, the things that seem plausible are sometimes "untranslatable," for the societal and cultural posits of the present keep on making us revalue the past. Therefore, Princip, once known as a hero, and being embraced as such by the Yugoslav society, is now looked at through different prisms. A national has become plural, and the plurality brings the possibility of many singular readings, not only the generally accepted one. Finally, Butcher's own quest is a personal reclaim for family history. His family truth, his embraced truth and his personal truth are changing constantly with every new step he makes following the Princip's footsteps. In that way, he is reclaiming the forgotten history of his family member as well as all the known and forgotten histories of all the people whose lives had to be rewritten as a consequence of a shot fired from the Miljacka River's Latin Bridge on 28th June 1914.

\section{Dénouement}

Working extensively on the topic of the relationship between language and violence, Dawes $(2002,1)$ distinguishes between two models: "the emancipatory [one], which presents force and discourse as mutually exclusive, and the disciplinary mode, which presents the two as mutually constitutive." What is evident from the lingua-cultural considerations of Tim Butcher's The Trigger is a vast array of possibilities it opens for considerations. Tackling a topic so universally known and yet highly personal, the author calls us to distinguish between his, our and everyone else's truths and histories which are connected with the beginning of World War I and the assassin whose deed still has a vast influence on our lives, for it changed the course of history.

Linguistic narrative, from the childlike "Us against Them, God against Evil" (Butcher 11), develops into a quest, which reclaims the lost life opportunities of the author's uncle, who died in World War I. It also rewrites the history of Gavrilo Princip by literally following his paths and trying to understand his views by investigating the land and the people he lived with.

Finally, it is worth mentioning that the subjectivity of the reclaimed uncle's past and rewritten Princip's history never ceases to be a personal one. We are constantly being reminded that what we are witnessing is just another piece in the puzzle called Gavrilo Princip and that the evidence gathered is open to reevaluation, for it consists only of stories the author chooses to include. The feeling of loss and emptiness war brings is personal and cannot be weighed or compared. Butcher poses the first and final question: "Could war ever end for relatives troubled by the knowledge that the remains of a loved one had never been found?" (25). The evident problem with answering such a question raises also gives us further possibilities to look at ourselves and inspect the events of 
our everyday activities. In the end, Princip will remain both a villain and a hero for some time, maybe even longer for the peoples of the country he was born in. This personal history may remain personal, but by being read, by exercising the power its tale possesses, it may somehow leave a mark on ours as well.

\section{Works Cited:}

Agar, Michael. "The biculture in bilingual." Language in Society 20 (1991): 167-181.

Agar, Michael. Language Shock. Understanding the Culture of Conversation. New York: William Morrow, 1994.

Atkinson, Dwight. "Writing across cultures: culture in second language writing studies." The Routledge Handbook of Language and Culture. Ed. Farzad Sharifian. London and New York: Routledge, 2015. 417-430.

Bracewell, Wendy and Alex Drace-Francis, eds. Under Eastern Eyes: A Comparative Introduction to East European Travel Writing on Europe. Budapest and New York: Central European University Press, 2008.

Butcher, Tim. The Trigger: Hunting the Assassin Who Brought the World to War. New York: Grove Press, 2014.

Butler, Judith. Excitable Speech: A Politics of the Performative. New York and London: Routledge, 1997.

Çelebi, Evliya. Seyahatnâmesi. Beyoğlu, İstanbul: Yapı Kredi Yayınları Ltd. Şti., 1996.

Crozet, Chantal and Anthony J. Liddicoat. "Teaching culture as an integrated part of language: Implications for the aims, approaches and pedagogies of language teaching." Teaching Languages, Teaching Cultures. Ed. Anthony J. Liddicoat and Chantal Crozet. Applied Linguistics Association of Australia, Melbourne, Vic: Language Australia, 2000. 1-22.

Dankoff, Robert and Sooyong Kim. An Ottoman Traveller: Selections from the Book of Travels of Evliya Çelebi (2nd ed.). London: Eland Publishing Limited, 2011.

Davidson, Robyn, ed. The Picador Book of Journeys. London: Picador, 2002.

Dawes, James. The Language of War: Literature and Culture in the U.S. from the Civil War through World War II. Cambridge, MA and London: Harvard University Press, 2002.

Dörnyei, Zoltán. Research Methods in Applied Linguistics. Oxford: Oxford University Press, 2007.

Fairclough, Norman, ed. Critical Language Awareness. London and New York: Longman, 1992.

Gladkova, Anna. "Ethnosyntax." The Routledge Handbook of Language and Culture. Ed. Farzad Sharifian. London and New York: Routledge, 2015. 33-50.

Goldsworthy, Vesna. Inventing Ruritania: The Imperialism of the Imagination. Oxford: Oxford University Press, 2012. 
Hanenberg, Peter. "Intersecting 'nature' and 'culture': How the study of culture could enhance cognitive science." Theorizing and Analyzing Conceptual Transfers. Ed. Nora Berning, Ansgar Nunning and Christine Schwanecke. Trier: WVT, 2014. 185-202.

Hanenberg, Peter, ed. A New Visibility: On Culture, Translation and Cognition. Lisboa: Universidade Católica Editora, 2015.

Hanenberg, Peter. "Intramental Translation: How culture shapes the mind or why Columbus did not discover America." La circolacione dei saperi in Occidente. Teoria e prassi della traduzione litteraria. Ed. Fabio Scotto and Marina Bianchi. Milano: Cisalpino, 2018. 1-26.

Krivokapić, Marija and Armela Panajoti. "On Postcolonial Influence in Balkan Travel Writing." Journal of Balkan and Near Eastern Studies. 20.2 (2018): 183-195.

Langacker, Ronald W. "Culture, cognition, and grammar." Language Contact and Language Conflict. Ed. Martin Pütz. Amsterdam and Philadelphia: John Benjamins Publishing, 1994. 25-53.

Lisle, Debbie. The Global Politics of Contemporary Travel Writing. Cambridge: Cambridge University Press, 2006.

Markovich, Slobodan G. "Anglo-American Views of Gavrilo Princip." Balcanica 46 (2015): 273-314.

Palmer, Gary B. Toward a Theory of Cultural Linguistics. Austin, TX: University of Texas Press, 1996.

Podesva, Robert J. and Devjani Sharma, eds. Research Methods in Linguistics. Cambridge: Cambridge University Press, 2013.

Pratt, Mary Louise. Imperial Eyes: Travel Writing and Transculturation. London and New York: Routledge, 1992.

Risager, Karen. Det nationale dilemma i sprog-og kulturpædagogikken. Et studie i forholdet mellem sprog og kultur. Copenhagen: Akademisk Forlag, 2003.

Risager, Karen. Language and Culture: Global Flows and Local Complexity. Clevedon: Multilingual Matters, 2006.

Risager, Karen. Language and Culture Pedagogy: From a National to a Transnational Paradigm. Clevedon-Buffalo-Toronto: Multilingual Matters Ltd, 2007.

Sharifian, Farzad. Cultural Linguistics. Amsterdam and Philadelphia: John Benjamins Publishing, 2017.

Sinclair, John. Trust the Text: Language, Corpus and Discourse. London and New York: Routledge, 2004.

Smethurst, Paul. "'Habits of a landscape': the geocritical imagination in Robert Macfarlane's The Wild Places and The Old Ways." New Directions in Travel Writing Studies. Ed. Julia Kuehn and Paul Smethurst. Basingstoke: Palgrave Macmillan, 2015. 97-110. 
Tannen, Deborah. That's Not What I Meant!: How Conversational Style Makes or Breaks Relationships. New York: Ballantine, 1986.

Thompson, Carl. Travel Writing. London and New York: Routledge, 2011.

Thompson, Carl, ed. The Routledge Companion to Travel Writing. London and New York: Routledge, 2016.

West, Rebecca. Black Lamb and Grey Falcon: A Journey Through Yugoslavia. London: Penguin Group, 2007.

Wierzbicka, Anna. Cross-Cultural Pragmatics: The Semantics of Human Interaction (2nd edition). Berlin and New York: Mouton de Gruyter, 2003.

\section{KAD TVOJE I MOJE (NI)JESU NAŠE: TRAGOM POTRAGE ZA LIČNIM I NACIONALNIM POVIJESTIMA U ROMANU THE TRIGGER: HUNTING THE ASSASSIN WHO BROUGHT THE WORLD TO WAR TIMA BUTCHERA}

lako je Prvi svjetski rat završio prije jednog vijeka, sasvim je jasno da njegovo prisustvo i posljedice i dalje odzvanjaju u (pod)svijesnom jastvu naroda na području Zapadnog Balkana. Rad se usredsređuje na otkrivanje mogućih jezičkih osobina unutar književnog teksta, koje razotkrivaju odnos autora prema kulturološkim i istorijskim događajima koje opisuje. Cilj je da se, kroz jezičke alatke koje se koriste, istraži mogućnost izdvajanja paralelnih ličnih i opštih istorija i tačaka na kojima se one preklapaju, bilo da su kulturološke ili istorijske. Glavni fokus je na suprostavljanju informacija u prikazanim pričama, čije je značenje jasno oblikovano kulturom(ama) govornika i opšte privaćenim kulturološkim i istorijskim stavovima.

Ključne riječi: kultura, istorija, putopisna književnost, jezičke osobine, intramentalni prevod. 